\title{
Resumption of cyclic ovarian activity in postpartum ewes: a review
}

\section{Retorno da atividade ovariana cíclica pós-parto de ovelhas: uma revisão}

\author{
Ivan Júnior Ascari ${ }^{1}$; Nadja Gomes Alves ${ }^{2 *}$; Ana Carolina Alves \\ Iraídes Ferreira Furusho Garcia ${ }^{2}$; Felipe Barbosa Junqueira ${ }^{4}$
}

\begin{abstract}
The reproduction rate is considered a crucial factor that affects the ability of producers to meet the growing demand for ovines meat, and optimizing this factor will maximize the production rate and increase the efficiency of livestock. A reduction in the length of the postpartum anestrus period results in a shorter interval between lambing and conception and enables more lambs to be produced throughout the life of a ewe. This review discusses the current knowledge of several factors associated with the resumption of cyclic ovarian function in postpartum ewes and how the suckling management of ewes may affect this process. Factors that influence the resumption of cyclic ovarian activity include uterine involution, follicular development, occurrence of silent ovulation and short estrous cycles, breed, reproductive seasonality, nutrition and lactation. Controlled suckling and early weaning are management practices that may be used to obtain three lambings in a 24-month period. In the majority of the studies the interval between lambing and first estrus was reduced when a controlled suckling management strategy was used, therefore the controlled suckling appears to be the best alternative because it has produced good results and is easy to implement. Currently, however, this practice is still not widely used.
\end{abstract}

Key words: Controlled suckling. Early weaning. Follicular development. Nutrition.

\section{Resumo}

A taxa de reprodução é considerado um fator crucial que afeta a capacidade dos produtores em atender a crescente demanda por carne ovina e otimizar esse fator pode maximizar a taxa de produção e aumentar a eficiência da pecuária. A redução da duração do período de anestro pós-parto resulta em um intervalo menor entre a parição e concepção e permite que mais cordeiros sejam produzidos durante toda a vida de uma ovelha. Esta revisão discute o conhecimento atual de vários fatores associados com o retorno da função ovariana cíclica pós-parto em ovelhas e como o regime de amamentação de ovelhas podem afetar esse processo. Fatores que influenciam o retomada da atividade ovariana cíclica incluem involução uterina, o desenvolvimento folicular, a ocorrência de ovulação silênciosa e ciclos estrais curtos, raça, sazonalidade reprodutiva, nutrição e lactação. A amamentação controlada e o desmame precoce são práticas de manejo que podem ser utilizados para se obter três partos em um período de 24 meses. Na maioria dos estudos, o intervalo entre o parto e o primeiro estro foi reduzido quando o manejo de amamentação controlada foi utilizado, portanto, a amamentação controlada parece ser a melhor

${ }^{1}$ Discente do Curso de Doutorado do Programa de Pós-Graduação em Zootecnia, Universidade Federal de Lavras, UFLA, Lavras, MG, Brasil. E-mail: ivan_ascari@hotmail.com

${ }^{2}$ Prof $^{\text {as }}$ Dr $^{\text {as }}$, Dept ${ }^{\mathrm{o}}$ de Zootecnia, UFLA, Lavras, MG, Brasil. E-mail: nadja@dzo.ufla.br; iraides.ufla@gmail.com

3 Discente do Curso de Mestrado do Programa de Pós-Graduação em Ciências Veterinárias, UFLA, Lavras, MG, Brasil. E-mail: anacveterinaria@hotmail.com

${ }^{4}$ Discente do Curso de Mestrado do Programa de Pós-Graduação em Zootecnia, UFLA, Lavras, MG, Brasil. E-mail: felipe_ argirita@hotmail.com

* Author for correspondence 
alternativa, pois tem apresentado bons resultados e sua implementação é fácil. Atualmente, no entanto, essa prática ainda não é amplamente utilizada.

Palavras-chave: Amamentação controlada. Desmame precoce. Desenvolvimento follicular. Nutrição.

\section{Introduction}

The recent increase in ovines meat consumption has increased the demand for lamb production; therefore, the current production techniques need to be improved. The reproduction rate is considered a crucial factor that affects the ability of producers to meet the growing demand for ovines meat, and optimizing this factor will maximize the production rate and increase the efficiency of livestock.

With the growth of the ovines production industry, the current goal of the industry is to reduce the lambing interval to obtain three lambings in two years, consequently increasing the production of lambs during the ewe's reproductive life. In this context, the duration of postpartum anestrus is one of the most important economic factors because a shorter interval between lambing and the onset of cyclic ovarian activity would allow for a new conception to occur in a shorter amount of time.

Several factors influence the resumption of ovarian activity in postpartum ewes, such as the lambing season, lactation, frequency and intensity of suckling, nutrition and breed. Among these factors, nutrition and body condition are known to play an important role; these factors affect follicular development through several endocrine, metabolic, and neural mechanisms and consequently influence the intervals between lambing and first estrus and between lambing and first ovulation. Therefore, adequate nutritional support during the early postpartum period is necessary for the animals to resume early ovarian activity.

The weaning process may help to reduce the effects of suckling on reproduction. A reduced postpartum anestrus was observed in Pelibuey (MORALES-TERÁN et al., 2004) and Santa Inês (ASSIS et al., 2011) ewes subjected to controlled sucking and in Préalpes de Sud (SCHIRAR et al., 1989) and Pelibuey (HERNANDEZ et al., 2009) ewes subjected to early weaning compared with ewes subjected to continuous suckling. These findings suggest that manipulating the suckling stimulus is an alternative management strategy that provides the quickest resumption of cyclic ovarian activity in these postpartum animals. However, even though this strategy is a low-cost practice, it is still not widely used in commercial herds.

This review summarizes the results obtained from studies investigating the most important factors influencing the resumption of cyclic ovarian activity in postpartum ewes, with emphasis on the management of suckling. Understanding these factors will help to design management practices that improve the reproductive rates and contribute to more efficient practices in the field.

\section{Uterine involution}

The resumption of normal ovarian activity and uterine involution are processes that occur in the reproductive system during the interval between lambing and first estrus (HAFEZ, 2004). Uterine involution is a process that occurs in preparation for the resumption of the estrous cycle and comprises three events: reduction in uterine size, tissue loss and tissue repair (GRAY et al., 2003). During the first week after parturition, the placentomal vasculature degenerates and the uterine lumen is filled with lochia a dense brown exudate produced by autolysis of the endometrial erythrocytes. Besides occurs dissolution of the fetal and maternal blades of the placentones and expulsion of the remaining cotyledons. During the second week, necrotic plaques are released at in caruncular involution, and the lochia becomes 
less dense and more transparent (VAN WYK et al., 1972). During the third and fourth weeks occurs the reepithelialization of the caruncles along with the decrease of the uterine tissue mass as seen by the marked loss in uterine weight (O'SHEA; WRIGHT, 1984).

Uterine involution is not a fertility barrier in ewes up to five to six weeks postpartum unless the process is delayed due to inflammation or infection (KIRACOFE, 1980). Hauser and Bostedt (2002) evaluated the diameter of the uterine lumen and the caruncles in German Lend ewes during the first 30 days postpartum and found that uterine regression in ewes is completed at approximately day 17 postpartum; however, the process was delayed in ewes that experienced obstetric interventions, caesarean section, and retention of fetal membranes.

Approximately 17 to 35 days is required for macroscopic uterine involution (HAUSER; BOSTEDT, 2002; ZDUNCZYK et al., 2004). According to Rubianes et al. (1996) the variation in the reproductive status of the control ewes and/ or the time of year when the study was conducted can explain the discrepancies in the results reported in the literature. These authors conducted two experiments in a subtropical region using Corriedale ewes. Using laparotomy, they evaluated uterine involution by measuring the length from the utero-tubal junction to the intercornual ligaments of both uterine horns. Ewes that lambed during the fall, regardless of whether they suckled their lambs, were compared with cyclic ewes, and ewes that lambed during the spring, regardless of whether they suckled their lambs, were compared with ewes in anestrus. The authors found that the uteri from animals that lambed during the fall were similar in size and weight to the uteri from cyclic ewes immediately after the second week postpartum, and these values remained similar after this period. This observation may be associated with an early resumption of postpartum ovarian endocrine function. Macroscopic uterine involution, however, took longer in ewes that lambed during the spring compared with the ewes in anestrus. Weaning immediately after lambing did not influence the time required for uterine involution.

Other studies have also shown that suckling does not influence uterine involution. Godfrey et al. (1998) evaluated uterine involution in St. Croix White ewes from a tropical region at different times of the year. The ewes were either exposed or not exposed to rams and either did or did not suckle their lambs. These authors observed that the size of the uterus at 25 days postpartum was similar to the size of the uterus from a non-pregnant animal. Involution was complete by 28 days postpartum, and there was no difference in the cross-sectional area of the uterine horns regardless of exposure to rams, the time of year and the number of lambs born. Similarly, Gonzalez-Stagnaro et al. (2002) studied West African ewe in a tropical region and reported that uterine involution is evident at 22 to 24 days postpartum and completed by 30 days postpartum. There was no difference between the animals that suckled their lambs and the animals that did not suckle their lambs.

It has also been shown that parity does not affect uterine involution. Zdunczyk et al. (2004) monitored Polish Longwool ewes by ultrasound and observed that uterine involution was completed earlier in primiparous ewes compared with multiparous ewes (25 vs 35 days postpartum); however, this difference was not significant. Hayder and Ali (2008) found a similar result when they evaluated the effects of parity and lambing season in Farafra ewes. Only the lambing season had an effect on uterine involution. In ewes that lambed in late winter, uterine involution was complete by 29 days postpartum, whereas in ewes that lambed in early summer, uterine involution was complete by 33 days postpartum. There was no correlation between uterine involution and the onset of postpartum luteal activity. 


\section{Follicular development}

Understand the pattern ovarian follicle development is seen as an important step leading to the development of techniques that maximise fertility in ewes (EVANS, 2003). Much of what is currently known on follicular dynamics in domestic animals was made possible by the application of ultrasonography to study ovarian follicular development (ABDEL-MAGEED; EL-MAATY, 2011; GINTHER, 2014) and luteal function, and in fact has caused the revision of the theories about the follicular dynamics patterns and existence of the degree of follicular dominance (GONZALEZBULNES; VEIGA-LOPEZ, 2005).

For successful reproduction to occur, follicles must develop through several stages within the ovary (SULLIVAN et al., 2013). Follicle development depends on the balance between survival factors, proliferation and cell death, which determine whether the follicle starts and continues to grow or is removed from the ovary (ROSALESTORRES et al., 2012). As the follicles develop towards the ovulatory stage, three features appear to be highly conserved across all species: the sequence of events (recruitment, selection and dominance), the sequential need for gonadotropins and the large variability of numerical parameters (number of waves per cycle, number of follicles per wave) as well as temporal requirements (time of selection, duration of dominance) (DRIANCOURT, 2000).

For a successful reproduction, the follicles must develop through several stages within the ovary (SULLIVAN et al., 2013). Follicular development is dependent on the balance between survival factors, proliferation and cell death, which determines the start and continuation of follicle growth, or if it is removed from the ovary (ROSALES-TORRES et al., 2012). As follicles develop following ovulatory stages. Three characteristics seem to be highly conserved in all species: the sequence of events (recruitment, selection and dominance), the sequential need of the gonadotropins and the great variability of numerical parameters (number of waves per cycle, and the number of wave per follicles) and time requirements (selection time until duration of dominance) (DRIANCOURT, 2000).

Patterns of ovarian follicular development in ewes are characterised by the appearance of antral follicles that grow continuously until it ovulate or become atresic (GONZALEZ-BULNES; VEIGALOPEZ, 2005). Follicle development can be divided into three phases: gonadotrophin-independent, gonadotrophin-responsive and gonadotrophindependent. Therefore, the phase from primordial follicle initiation to the preantral final phase is called the gonadotrophin-independent; the phase from the small antral to the large antral stage is called the gonadotrophin-dependent as follicles of this size do not occur in the absence of critical threshold concentrations of the pituitary gonadotrophins, LH and FSH; and the intermediate gonadotrophinresponsive phase in which follicles will respond to the actions of gonadotrophins but do not require them for normal growth and development (CAMPBELL, 2009).

In ewe, the ovarian steroids (progesterone $\left(\mathrm{P}_{4}\right)$ and estradiol $\left(E_{2}\right)$ ) provide feedback control of reproductive neuroendocrine function, with each hormone affecting both the tonic and surge modes of GnRH and LH secretion. This negative feedback occur during the last third portion of the gestation period. The recovery of the hypothalamic-pituitary axis in postpartum occurs with relatively infrequent GnRH pulses in the hypothalamic-pituitary system that stimulate the biosynthesis of the $\mathrm{LH}$ in the gonadotropes. However, the intervals between the GnRH pulses are only sufficient to stimulate the release of only a small portion of the newly synthesized LH. The increased synthesis rate combined with a slow release allows that the LH be stored in the pituitary. When the level of LH stored in the pituitary is within the normal range, the amplitude of the LH pulses released into circulation is sufficient to stimulate ovarian follicular development and $\mathrm{E}_{2}$ secretion, and the frequencies 
of the GnRH and LH pulses increase and stimulate the final stages of follicular development and ovulation. (NETT, 1987).

Gonzalez et al. (1987) evaluated laparotomized Pelibuey ewes for two consecutive years at 10 , 20, and 30 days postpartum. In the first year, these authors observed follicles with diameters of $4.7,5.2$ and $5.7 \mathrm{~mm}$ at 10,20 , and 30 days postpartum, respectively. In the second year, the follicle diameters were 4.3 and $4.1 \mathrm{~mm}$ at 10 and 20 days postpartum, respectively. On average, the first postpartum ovulation occurred at 26 days, and the interval until the first estrus was 51 days. There were also one, two or three ovulations without a noticeable behavioral estrus during this period. Some ewes had shorter cycles, and the $\mathrm{P}_{4}$ plasma concentration was below the normal range observed during normal length or silent estrous cycles.

Bartlewski et al. (2000) evaluated follicular development in Western white-faced crossbred ewes using ultrasonography during early pregnancy (days 10, 25, 30, 45 and 50) and at 13-29 days postpartum. These authors reported that animals with a corpus luteum (CL) in only one ovary during pregnancy had follicles no larger than $3.0 \mathrm{~mm}$ until 21 days postpartum. Ewes with CL in both ovaries during pregnancy had follicles no larger than 3.0 mm until 25 days postpartum. Follicles larger than $5.0 \mathrm{~mm}$ were observed in both ovaries at 27 and 28 days postpartum.

The distribution of healthy follicles and atresic on the ovaries surface of Valachian ewes in the spring puerperal period $(17,24$, and 32 days postpartum) was reported by Vlcková et al. (2012). The number of healthy follicles was higher on day 24 postpartum and their mean diameter tended to increase at day 32 with the greatest diameter of 5 mm. Was observed $78-81 \%$ of atretic follicles with $\geq 3 \mathrm{~mm}$ diameter which start at apoptosis in the follicular cells situated at the follicular cavity. At one ewe with 24 days postpartum, small regressive follicular cysts were observed. Progesterone and oestradiol-17 $\beta$ concentrations were maintained at relatively low levels, but with no significant difference between the postpartum days.

Evaluating Santa Ines ewes with lambs on continuous suckling, or ewes with lambs on controlled sucking (two time per day daily suckling) and ewes subjected to early weaning (up to 60 days postpartum), Ascari et al. (2013), did not find differences in the maximum follicular diameters (5.7, 5.9, and $5.6 \mathrm{~mm})$. Similarly, the interval between lambing and the occurrence of the first follicle with a diameter greater than or equal to 5 $\mathrm{mm}$ (31.0, 33.9 and 34.9 days) did not differ among treatments.

In ewes, follicles with size greater than or equal to $5 \mathrm{~mm}$ can be considered ovulatory (BARTLEWSKI et al., 2000). The ovaries of ewes in the first month after parturition are in relative inaction (VLCKOVÁ et al., 2012), but as shown, around the first month after parturition, ewes may have follicles with ovulatory size, however, one should take into account that different sizes found in the follicles may be related to the different breeds.

\section{Silent ovulation and short estrous cycles}

The $\mathrm{P}_{4}$ plasma concentration has been utilized to monitor ovarian activity in different species, in which a concentration greater than or equal to $1 \mathrm{ng} /$ $\mathrm{mL}$ is considered indicative of ovulation (ASHWAG; NOUR, 2015). In ewes, silent ovulations can occur (UNGERFELD et al., 2005) and are related to an insufficient production of steroids by the ovarian follicles (SHARPE et al., 1986) and to the absence of a $\mathrm{P}_{4}$-secreting $\mathrm{CL}$ after delivery (LASSOUED et al., 2004). According to Allrich (1994), because of the high levels of $E_{2}$, the hypothalamus appears to become resistant to $\mathrm{E}_{2}$, which is associated with an absence of a behavioral estrus before the first postpartum ovulation. The hypothalamus becomes less resistant to $\mathrm{E}_{2}$ after exposure to the $\mathrm{P}_{4}$ secreted during the first luteal phase postpartum and responds to $\mathrm{E}_{2}$ exposure in the subsequent cycle. 
The first spontaneous or induced ovulation after calving is associated with the CL of short lifespan (INSKEEP; DAILEY, 2004). These short cycles last 3-4 days and the concentration of the $\mathrm{P}_{4}$ rarely exceeds $1 \mathrm{ng} / \mathrm{mL}$ (UNGERFELD et al., 2004). The physiological mechanisms surrounding short cycles remain elusive. The alternative hypothesis to explain short cycles proposes that short cycles are results of the premature luteolysis and involve the uterus. Logically, they are either the result of a failure of the process of luteinisation and neovascularisation of the follicular remnants or the result of premature luteolysis (BROWN et al., 2014). Moreover, the follicles induced to ovulate are of poor quality, especially the follicles present a low granulosa cell quality. The CL developed from these follicles have an abnormal development leading to an insufficient proportion of the large luteal cells, and thus secrete lower quantities of the $\mathrm{P}_{4}$ conducing to lower concentrations in the blood of the ovarian vein and general circulation (CHEMINEAU et al., 2006).

The lack of exposure of the uterus to $\mathrm{P}_{4}$ and estrogen before to first postpartum ovulation decreases the concentration of $\mathrm{P}_{4}$ receptors and up regulates oxytocin receptors. The insufficient $\mathrm{P}_{4}$ receptor and presence of endometrial oxytocin receptors allows premature release of $\mathrm{PGF}_{2} \alpha$ and the resultant regression of the CL. Apparently, the $\mathrm{P}_{4}$ regulates secretion of the $\mathrm{PGF}_{2} \alpha$ by timing the initial peaks of secretion early in the estrous cycle, and after that, by modulating the secretion of $\mathrm{PGF}_{2} \alpha$ luteal regression to be completed (PEREA; INSKEEP, 2008).

The occurrence of short cycles can be influenced by the types of management, for example, the use of 'ram effect', can induce ovulation followed by an abnormally short luteal phase (BROWN et al., 2014). Furthermore, the luteal phase and silent ovulation may be affected by suckling regimen, because the ewes were subjected to continuous suckling had lower occurrence of silent ovulation and short luteal phase compared to ewes that were subjected to controlled suckling or early weaning (ASCARI et al., 2013).

\section{Breed and Seasonality}

Most mammals from temperate regions that experience seasonal fluctuations in their food supply have evolved patterns of reproduction that restrict their breeding activity to a defined period of the year (MENASSOL et al., 2012). Seasonality of the reproductive activity in ewes is a normal phenomenon at breeds originating in regions with mid or high latitude (ROSA; BRYANT, 2003), which show distinct seasonal patterns on the ovarian function, with ovulatory cycles that occur at autumn and winter (reprodution season) and anovulation at spring and summer (anestrous season) (GOODMAN et al., 2010). The daily photoperiod it has been identified as the determinant factor of the seasonal reprodution while environmental temperature, nutrition, behaviour, lambing date and lactation period exerts a modulator effect (ROSA; BRYANT, 2003). The main reason a species with seasonal pattern of reproduction is to ensure that births occur at the optimal time of the year, usually spring, which allows the newborn grow under favourable conditions of temperature and food availability before of the winter (FORCADA; ABECIA, 2006). This ensures that, under normal conditions, all ewes stay pregnant earlier at the autumn and, given pregnancy time of five months, lambs born at the spring when environmental conditions maximize their chances of survival (GOODMAN et al., 2010).

The reproductive seasonality of most European wool ewes breeds, which are seasonally polyestrus, is a major obstacle for the reproduction of ovines for meat production because of the concentration of the lamb meat supply during a certain period of the year and the small number of lambs produced because of the large lambing interval (VIU et al., 2006). The first ovulation after parturition is determined by 
many factors and may to occur at 60-70 days after lambing, but typically will appear during breeding season in the autumn (VLCKOVÁ et al., 2012).

Melatonin is a hormone secreted by the pineal gland and mediates the response to changes in photoperiod in ewes (JAINUDENN et al., 2004). The pattern of melatonin secretion follows a circadian rhythm with a significant amount of secretion only occurring during the dark period of the day, and light acts as a suppressor. Thus, the shortest period of melatonin secretion is observed on long days, and its secretion level increases on the short days (ROSA; BRYANT, 2003).

The pattern of melatonin secretion modulates the frequency of GnRH secretion (FOSTER; JACKSON, 2006) with the consequent change in pulsatile secretion of LH (ROSA; BRYANT, 2003). During the anestrus season, the hypothalamic centers that regulate the tonic release of GnRH are especially sensitivity to the $\mathrm{E}_{2}$-negative feedback mechanism. Consequently, the LH pulse has a low frequency and low amplitude during this phase, which results in low ovarian activity and an estrogen level that is sufficient for inhibiting the tonic release of GnRH. Near the end of the seasonal anestrus, the LH secretion patterns are progressively restored, stimulating the production of estrogen by the ovarian follicles (BICUDO et al., 2003).

The sexual activity of the ewes is strongly influenced by photoperiod. However, the ewes are scattered around the world, and a unique general description of the seasonal reproduction in small ruminants can not be applied universally (FORCADA; ABECIA, 2006). The regions near to the equator line, where the photoperiod may change imperceptibly, the animals live at complex environments in which they are continually confronted with short- and long-term changes in a wide range of factors, such as photoperiod, nutrition and sociosexual signals, and the response of GnRH to these factors depends largely on genotype (MARTIN et al., 2004).

\section{Nutrition}

Nutritional status and body condition are some of the most important factors that determine the duration of postpartum anestrus. The nutrition plays an important role as it affects directly and indirectly both physiology and reproductive performance (LAZARIN et al., 2012), exerting a crucial influence on follicular growth and development affects ovulation rate (SCARAMUZZI et al., 2006). However, the exact mechanisms or even the identification of the signalling metabolic compounds by which nutrition affects reproductive function still need further clarification (MEZA-HERRERA et al., 2007).

Positive effects of nutrition on the reproduction has been described in ewes, particularly as related to ovulation rate (SOUZA et al., 2014) and follicle populations (SOMCHIT-ASSAVACHEEP et al., 2011). The definitions of effect of nutrition on the ovulation rate have been identified with static effect, dynamic effect and immediate effect (SCARAMUZZI et al., 2013). The nutrition improves ovulation rate in ewes due to an increase at body weight (static effect), or by changes at metabolic hormones (immediate effect). Both effects improves the ovulation rate by increasing the number of gonadotropin responsive follicles (GUTIERREZ et al., 2011).

Amongst many factors that affect the reproductive performance of ruminants, energy has the greatest impact (COSTA et al., 2011). An insufficient energy intake due to the quality or quantity of the diet can prolong postpartum anestrus. Energy intake affects a wide variety of endocrine, metabolic and neural mechanisms, including changes in the secretion of gonadotropins by the pituitary, $\mathrm{P}_{4}$ production by the $\mathrm{CL}$ during the estrous cycle and pregnancy, and changes in the sensitivity of the hypothalamic-pituitary axis to steroid hormones that influence ovarian activity. The effects of dietary energy are variable, and this variation is related to differences in the degree of 
caloric restriction, body condition score (BCS), and body weight (SHORT; ADAMS, 1988). Higher energy and protein intake in ewes subjected to overfeeding positively affects the diameter of the largest follicle of anovulatory waves (LAZARIN et al., 2012). The nutritional supplementation with high energy diets stimulates folliculogenesis decreasing the negative feedback to induce compensatory increases in folliculogenesis (SOMCHIT-ASSAVACHEEP et al., 2011). Thus with supplementation containing high energy diets, the high protein intake also acts positively increasing FSH pulses, oestrogen concentrations and improves the fertility rate in ewes (KIA et al., 2011).

Both high-food intake and low-food intake conditions can affect ovarian function by modulating the secretion of LH and FSH. The development of the ovarian follicles is also affected by changes in the concentrations of metabolic hormones, such as insulin, growth hormone, leptin, insulinlike growth factor 1 and neuropeptide Y, whose concentrations can be affected by the animal's body condition (SOUZA et al., 2010). These hormones have important roles in the control of the follicle growth and are probably to be mediators of the effects of nutritional intake on the ovulation rate, by acting to regulate the action of key reproductive hormones such as gonadotrophins and steroids at the follicles. Insulin is an important regulator of the folliculogenesis because the uptake of glucose is regulated by insulin, suggesting a role for insulin as a mediator in the mechanism of nutritional effects on ovulation (SCARAMUZZI et al., 2013).

\section{Postpartum body condition}

The BCS is defined as the amount of muscle and fat tissue stored in the body of the animal at a given moment of the productive and reproductive cycles and estimates the energy status of these physiological states. BCS is determined by a scale of 0 to 5 , in which $0=$ emaciated and $5=$ overfat
(GORDON, 1997). Changes in the BCS can be used to estimate changes in the body energy reserves more accurately than body weight fluctuations. Variables, such as water or food weight in the gastrointestinal tract, and the fetus in pregnant animals are included in the animal's weight; therefore, the amount of body energy reserves can be overestimated when it is determined by the body weight (CEZAR; SOUSA, 2006).

A reduced BCS affects productive and reproductive functions, including the duration of postpartum anestrus. Gonzalez-Stagnaro (1993) assessed the body condition of Criollo ewes when they lambed and demonstrated that a BCS below 1 affected the reproductive capacity compared with a BCS between 2 and 3. The interval between lambing and estrus was 20 days shorter in animals with a higher body condition, which also represents a $16 \%$ increase in fertility and an increase in prolificacy from 1.11 to 1.17 lambs. According to the author, postpartum anestrus will continue in ewes that have not recovered their body weight and body condition.

Gonzalez et al. (1987) assessed Pelibuey ewes exposed to varying forage availability during different years and observed that the animals' body weight at delivery was 25\% lower during the year when the forage availability was reduced. During this period of reduced forage availability, the interval from lambing to first estrus (91 vs 51 days) and the interval from lambing to first ovulation (59 vs 26 days) were longer and the diameter of the largest follicle was smaller $(6.0 \mathrm{vs} 7.7 \mathrm{~mm})$, demonstrating that the animal's nutritional state affects the resumption of ovarian cyclic activity.

According to Mbayahaga et al. (1998) weight loss is the main factor that controls the duration of postpartum anestrus in Burundian ewes. These authors compared the body weight loss and the duration of postpartum anestrus among ewes that were kept in a natural pasture and delivered during the middle of the dry season. The body weight decreased after lambing and correlated with the 
interval between lambing and first estrus and the interval between lambing and first ovulation. The ovarian activity was normal after the first ovulation.

Costa (2003) studied Santa Inês ewes kept in a pasture and subjected to the effects of continuous or controlled suckling, in which the lambs were separated from their mothers at 15 days postpartum and were subsequently allowed to suckle twice a day for one hour until being weaned at 60 days. This author did not find a difference in the body weight, body condition or the intervals between lambing and the first and second estrus. These results indicate that this management strategy did not affect the recovery of the ewes until the weaning.

Assis et al. (2011) studied Santa Inês and Bergamácia ewes subjected to one of the following three suckling regimens that started at 15 days postpartum and ended at weaning at 60 days: continuous suckling; controlled suckling with two daily suckling sessions, where the ewes were kept in a pasture during the day and in a pen during the night; and controlled suckling with a daily suckling session, where the ewes were kept in a pasture during the day and in a pen with their lambs during night. Weight and extracorporeal circulation were not influenced by the suckling management strategies used in the study. However, it is noteworthy that the individual nutrient intake of the animals kept in a pasture was not assessed.

Leite (2010) evaluated Santa Inês ewes subjected to continuous suckling, suckling twice a day or suckling only during the night and observed that the ewes not subjected to continuous suckling demonstrated less weight loss and a better body condition. According to Leite, this finding may be associated with a reduced intensity and/or reduced amount of time that the ewes remained in a negative energy balance because of their reduced fatigue associated with suckling and the longer period of time they had available for food intake. In contrast, Ascari et al. (2013) found that the different suckling management strategies (continuous, controlled, early weaning) had no effect on weight gain, body condition or non-esterified fatty acid concentrations in Santa Inês ewes.

Costa (2003) reports that in Santa Inês ewes the proper nutrition, which allows a ewe to lamb with a good body condition and to maintain this BCS during the postpartum period despite the adverse conditions associated with this period, restores the balance between all of the normal functions more quickly, contributes to greater milk production for the offspring, resulting in a higher performance of the lambs, and also contributes to an earlier resumption of reproductive activities.

\section{Suckling}

One of the main factors involved in the resumption of ovarian activity after parturition is suckling (TAKAYAMA et al., 2010). In the weaned animals, the time of weaning is an important factor the duration of postpartum anoestrus (RONQUILLO et al., 2008), and has been demonstrated that the suckling prolongs, in the ewe, the postpartum anovulatory period (HERNANDEZ et al., 2009).

In most mammalian species lactation suppresses fertility (MCNEILLY, 2001), which is a physiological state of the females in which the adaptations where in the hypothalamic function results in a reduction in reproductive functions and provide prolonged anestrus. These adaptive changes occur in a number of neural systems and it is difficult to define which one is manly involved in the modulation of the reproductive function, amongst the known inhibitors of the GnRH/LH system, endogenous opioid peptides play a crucial role (DOBEK et al., 2013).

It has been shown that the main cause of the postpartum anoestrus is not the failure of ovarian function but the inhibition of the pulsatile secretion of the GnRH and LH (RONQUILLO et al., 2008). The suckling actives a complex system of neural responses and hormonal feedback, bonds that 
result in the reduced of the LH pulse frequency and amplitude by altering GnRH release. This results at decreased or hindered for follicular development and absence of follicles eligible for ovulation (BISCHOFF et al., 2012). The quality of the follicles and corpora lutea created after ovulation is improved, and viable pregnancies may follow. This has direct relationship with prolificacy, which has been improved by restricted suckling and by early weaning, even in the mating season (RONQUILLO et al., 2008).

In ewes, the basal plasma concentrations of cortisol was higher in lactating ewes than nonlactating ewes (COOK, 1997). During lactation, there is an increase in the basal secretion of glucocorticoids and adrenocorticotropic hormone (ACTH) (LIGHTMAN et al., 2001), the glucocorticoids inhibits the pulsatile secretion of the GnRH and LH in the hypothalamus and pituitary (WAGENMAKER et al., 2009) which causes delays in the pre-ovulatory surge of $\mathrm{LH}$ and therefore ovulation (ARROYO et al., 2011). Moreover, is suggested that the endogenous peptides are involved in the regulating the $\mathrm{GnRH} / \mathrm{LH}$ axis activity in lactating ruminants, however, little is known about this involvement (DOBEK et al., 2013).

Azevedo et al. (2002) found no difference in the interval between birth and the first ovulation in Ile de France ewes that suckled their lambs continuously or only during the night. A value greater than $0.5 \mathrm{ng} / \mathrm{mL}$ in blood samples collected twice weekly beginning one week after lambing was used to determine the occurrence of the first ovulation. Unlike, MoralesTerán et al. (2004) reported that limiting suckling to two 30-minute periods in Pelibuey ewes resulted in an earlier resumption of ovarian activity postpartum (53.6 days) compared with continuous suckling, in which lambs were kept with their mothers for 24 hours a day (60.5 days).

Evaluating the use of hormonal treatment (intravaginal progestagen plus eCG) with weaning at seven or 40 days postpartum, or restricted suckling,
Ronquillo et al. (2008) observed improves in the postpartum reproductive efficiency in Pelibuey ewes, in at response to the hormonal treatments, if suckling is restricted to $30 \mathrm{~min}$ day and if weaning begins on day seven postpartum. The number of ewes with external signs of oestrus before 30 days postpartum was greatest in ewes in which suckling was restricted or weaning was imposed at day seven postpartum. According to the authors, the percentage of the ewes pregnant was superior in weaned ewes, possibly because these ewes avoided had the short-life CL that can be produced as an indirect effect of suckling. The high pregnancy rate with restricted suckling and early weaning can be explained by the fact that these treatments reduce the duration of postpartum anoestrus so that various ewes within these groups had cycle before the hormonal regimens were begun.

Hernandez et al. (2009) evaluated the effect of suckling on the interval between lambing and the first ovulation postpartum in Pelibuey ewes. The experimental groups consisted of animals subjected to continuous suckling, in which the lambs remained with the mother 24 hours a day; controlled suckling, in which the lambs were allowed to suckle twice a day for 30 minutes; or early weaning, in which the lambs were separated from the ewes at 7 days postpartum. Plasma $\mathrm{P}_{4}$ levels higher than $0.5 \mathrm{ng} / \mathrm{mL}$ in two consecutive samples or greater than $1 \mathrm{ng} / \mathrm{mL}$ in a single sample (two collections per week) indicated the occurrence of ovulation. Early weaning and controlled suckling reduced the interval between lambing and first ovulation compared with continuous suckling (39.0, 41.9, and 52.6, days, respectively).

Assis et al. (2011) assessed the return to estrus in Santa Inês and Bergamácia ewes. These authors compared the regimen of continuous suckling, suckling limited to twice daily or suckling only at night. The suckling limited to twice a day reduced the interval from lambing to first estrus compared with continuous suckling ( 36.7 vs 49.1 days), and there was no difference between the breeds. The 
suckling management strategy, type of delivery, and breed did not affect the resumption of ovarian activity after lambing, which was 42.8 and 35.8 days in the Santa Inês and Bergamácia ewes, respectively.

Suckling management can cause psychological stress in ewes, which most likely inhibits pulsatile LH secretion and promotes the delay in postpartum ovulation (ARROYO et al., 2011). The postpartum anestrus was shorter in Pelibuey ewes that constantly remained with their lambs (58.8 days) compared with those ewes that only suckled 17 hours per day (83.2 days). In this study, $100 \%$ of the ewes subjected to continuous suckling ovulated within 105 days postpartum, while only $64.7 \%$ of the ewes subjected to controlled suckling ovulated within the same period of time.

Ascari et al. (2013) compared Santa Inês ewes subjected to continuous suckling, controlled suckling (two daily feedings) or early weaning up to 60 days postpartum. These authors found no difference in the percentages of ewes in estrus and ewes that ovulated. Additionally, there was no difference in the interval between lambing and estrus and the interval between lambing and ovulation as well as no difference in the serum prolactin levels. The ovulation rate in the first 30 days was higher in the group of ewes subjected to early weaning.

\section{Final Considerations}

The resumption of the ovarian cycle postpartum in ewes is affected by many factors. Factors such as the breed, the nutritional and suckling management strategies adopted, the presence of visual and auditory stimuli between the ewe and lamb as well as the criteria used to define the resumption of ovarian activity may partially be responsible for the discrepancies in the existing results in the literature regarding suckling management strategies. Controlled suckling does not appear to significantly affect the timing of the first ovulation when compared with continuous suckling or early weaning. In the majority of the studies, however, the interval between lambing and first estrus was reduced when a controlled suckling management strategy was used.

\section{Acknowledgments}

The present study was supported by the Minas Gerais Research Foundation (Fundação de Amparo à Pesquisa do Estado de Minas Gerais, or FAPEMIG), the National Council for Scientific and Technological Development (Conselho Nacional de Desenvolvimento Científico e Tecnológico, or CNPq) and, Coordination for the Improvement of Higher Education Personnel (Coordenação de Apoio a Pessoal de Nível Superior or CAPES).

\section{References}

ABDEL-MAGEED, I. I.; EL-MAATY, A. M. A. Effect of body condition of rahmani ewes on their follicular development during the first ovulatory wave after estrous synchronization. Egyptian Society of Animal Production, Cairo, v. 48, n. 2, p. 167-172, 2011.

ALLRICH, R. D. Endocrine and neural control of estrus in dairy cows. Journal of Dairy Science, Champaign, v. 77, n. 9, p. 2738-2744, 1994.

ARROYO, J.; CAMACHO-ESCOBAR, M. A.; ÁVILASERRANO, N. Y.; HOFFMAN, J. A. Influencia del contacto restringido hembra-cordero em la durácion del anestro posparto em ovejas pelibuey. Tropical and Subtropical Agroecosystems, Merida, v. 90, n. 14, p. 643648, 2011.

ASCARI, I. J.; ALVES, A. C.; PÉREZ, J. R. O.; LIMA, R. R.; GARCIA, I. F. F.; NOGUEIRA, G. P.; JUNQUEIRA, F. B.; CASTRO, T. R.; AZIANI, W. L. B.; ALVES, N. G. Nursing regimens: effects on body condition, return to postpartum ovarian cyclicity in Santa Ines ewes, and performance of lambs. Animal Reproduction Science, Amsterdam, v. 140, n. 3, p. 153-163, 2013.

ASHWAG, E. M.; NOUR, M. S. M. The effect of seasons on sexual cycle of female desert goats on the basis of progesterone profiles. International Journal of Advanced Scientific and Technical Research, Visakhapatnam, v. 4, n. 5, p. 579-585, 2015. 
ASSIS, R. M.; PÉREZ, J. R. O.; SOUZA, J. C.; LEITE, R. F.; CARVALHO, J. R. R. Influência do manejo de mamada sobre o retorno ao estro em ovelhas no pósparto. Ciência e Agrotecnologia, Lavras, v. 35, n. 5, p. 1009-1016, 2011.

AZEVEDO, J. M.; CORREIA, T. M.; ALMEIDA, J. C.; VALENTIM, R. C.; FONTES, P.; MENDONÇA, A. Anestro pós-parto em ovelhas de diferentes raças: efeitos do regime de amamentação. Revista Portuguesa de Ciências Veterinárias, Lisboa, v. 97, n. 1, p. 129-134, 2002.

BARTLEWSKI, P. M.; BEARD, A. P.; RAWLINGS, N. C. Ultrasonographic study of ovarian function during early pregnancy and after parturition in the ewe. Theriogenology, New York, v. 53, n. 3, p. 673-689, 2000.

BICUDO, S. D.; SOUSA, D. B.; TAKADA, L. Possibilidades e limitações da inseminação com sêmen ovino refrigerado e biotécnicas associadas como estratégias de intensificação do manejo reprodutivo. Revista Brasileira de Reprodução Animal, Belo Horizonte, v. 27, n. 1, p. 120-127, 2003.

BISCHOFF, K.; MERCADANTE, V.; LAMB, C. Management of postpartum anestrus in beef cows. Gainesville: IFAS Extension Service, 2012. 4.p. Disponível em: <https://edis.ifas.ufl.edu/pdffiles/AN/ AN27700.pdf $>$. Acesso em: 13 jul. 2015.

BROWN, H. M.; NYS, C. F.; COGNIE, J.; SCARAMUZZI, R. J. Short oestrous cycles in sheep during anoestrus involve defects in progesterone biosynthesis and luteal neovascularisation. Reproduction, Cambridge, v. 147, n. 3, p. 357-367, 2014.

CAMPBELL, B. K. The endocrine and local control of ovarian follicle development in the ewe. Animal Reproduction Science, Amsterdam, v. 6, n. 1, p. 159-171, 2009.

CEZAR, M. F.; SOUSA, W. H. Avaliação e utilização da condição corporal como ferramenta de melhoria da reprodução e produção de ovinos e caprinos de corte. Revista Brasileira de Zootecnia, Viçosa, MG, v. 35, n. 7, p. 649-678, 2006.

CHEMINEAU, P.; PELLICER-RUBIO, M.; LASSOUED, N.; KHALDI, G.; MONNIAUX, D. Maleinduced short oestrous and ovarian cycles in sheep and goats: a working hypothesis. Reproduction Nutrition Development, Paris, v. 46, n. 4, p. 417-429, 2006.

COOK, C. J. Oxytocin and prolactin suppress cortisol responses to acute stress in both lactating and nonlactating sheep. Journal of Dairy Research, Cambridge, v. 64, n. 3, p. 327-339, 1997.
COSTA, R. L. D. Avaliação do peso e do retorno ao estro em ovelhas e do desempenho ponderal de cordeiros, em ovinso da raça Santa Inês, de acordo com o manejo de ammentação. 2003. Dissertação (Mestrado em Produção Animal) - Universidade Estadual do Norte Fluminense, Campos dos Goytacazes.

COSTA, R. L. D.; FONTES, R. S.; CUNHA, E. A.; BUENO, M. S.; QUIRINO, C. R.; AFONSO, V. A. C.; OTERO, W. G.; SANTOS, L. E.; DIAS, A. J. B. Reproductive performance of Santa Inês ewes fed protected fat diet. Pesquisa Agropecuária Brasileira, Brasília, v. 46, n. 6, p. 663-668, 2011.

DOBEK, E.; GÓRSKI, K.; ROMANOWICZ, K.; MISZTAL, T. Different types of opioid receptors involved in the suppression of LH secretion in lactating sheep. Animal Reproduction Science, Amsterdam, v. 141, n. 1, p. 62-67, 2013.

DRIANCOURT, M. A. Regulation of ovarian follicular dynamics in farm animals implications for manipulation of reproduction. Theriogenology, New York, v. 55, n. 6, p. 1211-1239, 2000.

EVANS, A. C. O. Ovarian follicle growth and consequences for fertility in sheep. Animal Reproduction Science, Amsterdam, v. 78, n. 3, p. 289-306, 2003.

FORCADA, F.; ABECIA, J. The effect of nutrition on the seasonality of reproduction in ewes. Reproduction Nutrition Development, Paris, v. 46, n. 4, p. 355-365, 2006.

FOSTER, D. L.; JACKSON, L. M. Puberty in the sheep. In: KNOBIL, E.; NEIL, J. D. The physiology of reproduction. $3^{\text {th }}$ ed. New York: Raven Press, 2006. p. 17-27.

GINTHER, O. J. How ultrasound technologies have expanded and revolutionized research in reproduction in large animals. Theriogenology, New York, v. 81, n. 1, p. 112-125, 2014.

GODFREY, R. W.; GRAY, M. L.; COLLINS, J. R. The effect of ram exposure on uterine involution and luteal function during the postpartum period of hair sheep ewes in the tropics. Journal of Animal Science, Champaing, v. 76, n. 12, p. 3090-3094, 1998.

GONZALEZ, A.; MURPHY, B. D.; ALBA, J. M. de; MANNS, J. G. Endocrinology of the postpartum period in the Pelibuey Ewe. Journal of Animal Science, Champaing, v. 64, n. 6, p. 1717-1724, 1987.

GONZALEZ-BULNES, A.; VEIGA-LOPEZ, A. Ovarian follicular dynamics and dominance effect in sheep. In: CONVEGNO NAZIONALE DELLA SOCIETA' ITALIANA DI FISIOLOGIA VETERINARIA, 6., 2005, Stintino. Proceedings... Stintino: Societa' Italiana Di Fisiologia Veterinaria, 2005. p. 31-34. 
GONZALEZ-STAGNARO, C. Comportamiento reproductivo de ovejas y cabras tropicales. Revista Cientifica, Zulia, v. 3, n. 1, p. 173-196, 1993.

GONZALEZ-STAGNARO, C.; FERREIRA, N. J.; BURY, N. M.; CHIRINOS, Z. Involución uterina en ovejas deslandas west african en el medio tropical. Revista Científica, Zulia, v. 12, n. 5, p. 329-337, 2002.

GOODMAN, R. L.; JANSEN, H. T.; BILLINGS, H. J.; COOLEN, L. M.; LEHMAN, M. N. Neural systems mediating seasonal breeding in the ewe. Journal of Neuroendocrinol, Malden, v. 22, n. 7, p. 674-681, 2010.

GORDON, I. R. Controlled reproduction in sheep and goats. $2^{\text {th }}$ ed. Oxford: CAB International 1997. $450 \mathrm{p}$.

GRAY, C. A.; STEWART, M. D.; JOHNSON, G. A.; SPENCER, T. E. Postpartum uterine involution in sheep: histoarchitecture and changes in endometrial gene expression. Reproduction, London, v. 125, n. 2, p. $185-$ $198,2003$.

GUTIERREZ, C. G.; FERRARO, S.; MARTINEZ, V.; SAHARREA, A.; CORTEZ, C.; LASSALA, A.; BASURTO, H.; HERNANDEZ, J. Increasing ovulation quota: more than a matter of energy. Acta Scientiae Veterinariae, Porto Alegre, v. 39, p. s305-s316, 2011. Supplement 1.

HAFEZ, E. S. E. Reprodução animal. 7. ed. São Paulo: Manole, 2004. 180 p.

HAUSER, B.; BOSTEDT, H. Ultrassonographic observations of uterine regression in the ewe under different obstetrical conditions. Journal of Veterinary Medical Science, Tokyo, v. 49, n. 10, p. 511-516, 2002.

HAYDER, M.; ALI, A. Factores affecting the postpartum uterine involution and luteal function of sheep in the subtropics. Small Ruminant Research, Amsterdam, v. 79, n. 2, p. 174-178, 2008.

HERNANDEZ, P. P.; VALDEZ, V. H.; SANDOVAL, B. F.; HERNÁNDEZ, G. T.; RIVERA, P. D.; SÁNCHEZ, J. G. Efecto del tipo de amamantamiento em la actividad ovárica postparto de ovejas Pelibuey y tasas de crescimiento de corderos em los primeros 90 dias de edade. Revista Cientifica, Zulia, v. 19, n. 4, p. 343-349, 2009.

INSKEEP, E. K.; DAILEY, R. A. Preovulatory, postovulatory, and postmaternal recognition effects of concentration of progesterone on embryonic survival in the cow. Journal of Animal Science, Champaing, v. 82, p. E24-E39, 2004. Supplement.

JAINUDENN, M. R.; WAHID, H.; HAFES, E. Ovinos e caprinos. In: HAFEZ, E. S. E. Reprodução animal. 7. ed. São Paulo: Manole, 2004. p. 173-182.
KIA, H. D.; CHAPDAREH, W. M.; KHANI, A. H.; MOGHADDAM, M.; RASHIDI, A.; SADRI, H.; ALIJANI, S. Effects of flushing and hormonal treatment on reproductive performance of Iranian Markhoz goats. Journal of Animal Physiology and Animal Nutrition, Berlin, v. 96, n. 6, p. 1157-1164, 2011.

KIRACOFE, G. H. Uterine involution: it is role in regulating postpartum intervals. Journal of Animal Science, Cambridge, v. 51, n. 1, p. 16-28, 1980.

LASSOUED, N.; NAOUALI, M.; KHALDI, G.; REKIK, $M$. Influence of the permanent presence of rams on the resumption of sexual activity in postpartum Barbarine ewes. Small Ruminant Research, Amsterdam, v. 54, n. 1, p. $25-31,2004$.

LAZARIN, G. B.; ALVES, N. G.; PEREZ, J. R. O.; LIMA, R. R.; GARCIA, I. F. F.; JOSÉ NETO, A.; VALE, D. N. C.; SAUNDERS, G. A. Plasma urea nitrogen and progesterone concentrations and follicular dynamics in ewes fed proteins of different degradability. Revista Brasileira Zootecnia, Viçosa, MG, v. 41, n. 7, p. 16381647, 2012.

LEITE, R. F. Restrição da amamentação: desempenho $e$ retorno ao estro das ovelhas, desempenho $e$ comportamento dos cordeiros. 2010. Dissertação (Mestrado em Zootecnia) - Universidade Federal de Lavras, Lavras.

LIGHTMAN, S. L.; WINDLE, R. J.; WOOD, S. A.; KERSHAW, Y. M.; SHANKS, N. Peripartum plasticity within the hypothalamo-pituitary-adrenal axis. Progress in Brain Research, Amsterdam, v. 133, n. 1, p. 111-129, 2001.

MARTIN, G. B.; RODGER, J.; BLACHE, D. A. Nutritional and environmental effects on reproduction in small ruminants. Reproduction, Fertility and Development, Clayton, v. 16, n. 4, p. 491-501, 2004.

MBAYAHAGA, J.; MANDIKI, S. N. M.; BISTER, J. L.; PAQUAY, R. Body weight, oestrous and ovarian activity in local Burundian ewes and goats after parturition in the dry season. Animal Reproduction Science, Amsterdam, v. 51, n. 4, p. 289-300, 1998.

MCNEILLY, A. S. Lactational control of reproduction. Reproduction, Fertility and Development, Clayton, v. 13, n. 1, p. 530-590, 2001.

MENASSOL, J.; COLLET, A.; CHESNEAU, D.; MALPAUX, B.; SCARAMUZZI, R. J. The Interaction between photoperiod and nutrition and its effects on seasonal rhythms of reproduction in the ewe. Biology of Reproduction, Madison, v. 86, n. 2, p. 1-12, 2012. 
MEZA-HERRERA, C. A.; ROSS, T.; HALLFORD, D.; HAWKINS, D.; GONZALEZ-BULNES, A. Effects of body condition and protein supplementation on LH secretion and luteal function in sheep. Reproduction in Domestic Animals, Berlin, v. 42, n. 5, p. 461-465, 2007.

MORALES-TERÁN, G.; MARTÍNEZ, A. P.; SANDOVAL, B. F.; REAL, C. S.; SÁNCHEZ, J. G. Amamantamiento continuo o restringido y su relación con La duración del anestro postparto en ovejas Pelibuey. Agrociencia, Montecillo, v. 38, n. 2, p. 165-171, 2004.

NETT, T. M. Function of the hypothalamic-hypophysial axis during the post-partum period in ewes and cows. Journal of Reproduction and Fertility, Cambridge, v. 34, p. 201-213, 1987. Supplement.

O'SHEA, J. D.; WRIGHT, P. J. Involution and regeneration of the endometrium following parturition in the ewe. Cell and Tissue Research, Berlin, v. 236, n. 2, p. 477-485, 1984.

PEREA, F. G.; INSKEEP, E. K. Infertility associated with the duration of luteal phase in postpartum cows. Asociación Latinoamericana de Producción Animal, Mar del Plata, v. 16, n. 3, p. 175-185, 2008.

RONQUILLO, J. C.; MARTÍNEZ, A. P.; PEREZ, C. M. B.; SANDOVAL, B. F.; MARTIN, G. B.; VALENCIA, J.; SANCHEZ, J. G. Prevention of suckling improves postpartum reproductive responses to hormone treatments in Pelibuey ewes. Animal Reproduction Science, Amsterdam, v. 107, n. 1, p. 85-93, 2008.

ROSA, H. J. D.; BRYANT, M. J. Seasonality of reproduction in sheep. Small Ruminant Research, Amsterdam, v. 48, n. 1, p. 155-171, 2003.

ROSALES-TORRES, A. M.; SÁNCHEZ, A. G.; AGUILAR, C. G. Follicular development in domestic ruminants. Tropical and Subtropical Agroecosystems, Merida, v. 15, n. 1, p. 147-160, 2012.

RUBIANES, E.; UNGERFELD, R.; VIFROLES, C.; CARBAJAL, B.; CASTRO, T.; LBARRA, D. Uterine involution time and ovarian activity in weaned and suckling ewes. Canadian Journal of Animal Science, Ottawa, v. 76, n. 1, p. 153-155, 1996.

SCARAMUZZI, R. J.; CAMPBELL, B. K.; DOWNING, J. A.; KENDALL, N. R.; KHALID, M.; MUNOZGUTIERREZ, M.; SOMCHIT, A. A review on the effects of supplementary nutrition in the ewe on the concentration of reproductive and metabolic hormones and the mechanisms that regulate folliculogenesis and ovulation rate. Reproduction Nutrition Development, Paris, v. 46, n. 4, p. 339-354, 2006.
SCARAMUZZI, R. J.; OUJAGIR, L.; MENASSO, J.; FRERET, S.; PIEZEL, A.; BROWN, H. M.; COGNIE, J.; NYS, C. F. The pattern of LH secretion and the ovarian response to the 'ram effect' in the anoestrous ewe is influenced by body condition but not by shortterm nutritional supplementation. Reproduction, Fertility and Development, Clayton, v. 26, n. 8, p. 11541165, 2013.

SCHIRAR, A.; COGNIE, Y.; LOUAULT, F.; POULIN, N.; LEVASSEUR, M. C.; MARTINETET, J. Resumption of oestrous behaviour and cyclic ovarian activity in suckling and non-suckling ewes. Journal of Animal Science, Champaing, v. 87, n. 2, p. 789-797, 1989.

SHARPE, P. H.; GIFFORD, D. R.; FLAVEL, P. F.; NOTTLE, M. B.; ARMSTRONG, D. T. First postpartum ovulations and corpora lutea in ewes which lamb in the breeding season. Animal Reproduction Science, Amsterdam, v. 10, n. 1, p. 61-74, 1986.

SHORT, E. E.; ADAMS, D. C. Nutritional and hormonal interrelathionships in beef cattle reproduction. Canadian Journal of Animal Science, Ottawa, v. 68, n. 1, p. 29-39, 1988.

SOMCHIT-ASSAVACHEEP, A. Influence of nutritional management on folliculogenesis in ewes anongnart somchit-assavacheep. The Thai Journal of Veterinary Medicine, Bangkok, v. 41, n. 1, p. 25-29, 2011.

SOUZA, F. A.; CANISSO, I. F.; BORGES, A. M.; VALE FILHO, V. R.; LIMA, A. L.; SILVA, E. C. Restrição alimentar e os mecanismos endócrinos associados ao desenvolvimento folicular ovariano em vacas. Revista Brasileira Reprodução Animal, Belo Horizonte, v. 33, n. 2, p. 61-65, 2010.

SOUZA, M. I. L.; GRESSLER, M. A. L.; URIBEVELÁSQUEZ, L. F. Interrelationships of nutrition, metabolic hormones and reproduction of female sheep. Revista CES Medicina Veterinaria y Zootecnia, Medellín, v. 9, n. 2, p. 248-261, 2014.

SULLIVAN, R. R.; R.; EBORN, D.; GRIEGER, D. M.; CINO-OZUNA, A. G.; ROZELL, T. G. Follicular expression of follicle stimulating hormone receptor variants in the ewe. Reproductive Biology and Endocrinology, London, v. 11, n. 1, p. 113-120, FARIS, B. 2013.

TAKAYAMA, H.; TANAKA, T.; KAMOMAE, H. Postpartum ovarian activity and uterine involution in non-seasonal Shiba goats, with or without nursing. Small Ruminant Research, Amsterdam, v. 88, n. 1, p. 62-66, 2010. 
UNGERFELD, R.; DAGO, A. L.; RUBIANES, E.; FORSBERG, M. Response of anestrous ewes to the ram effect after follicular wave synchronization with a single dose of estradiol-17ß. Reproduction Nutrition Development, Paris, v. 44, n. 1, p. 89-98, 2004.

UNGERFELD, R.; CARBAJALA, B.; RUBIANES, E.; FORSBERG, M. Endocrine and ovarian changes in response to the ram effect in medroxyprogesterone acetate-primed corriedale ewes during the breeding and nonbreeding season. Acta Veterinaria Scandinavica, London, v. 46, n. 1, p. 33-44, 2005.

VAN WYK, L. C.; VAN NIEKERK, C. H.; BELONJE, P. C. Involution of the post partum uterus of the ewe. Journal of the South African Veterinary Association, Durbanville, v. 43, n. 1, p. 19-26, 1972.

VIU, M. A. O.; OLIVEIRA FILHO, B. D.; LOPES, D. T.; VIU, A. F. M.; SANTOS, K. J. G. Fisiologia e manejo reprodutivo de ovinos: revisão. Revista Eletrônica Faculdade Montes Belos, Montes Belos, v. 1, n. 1, p. 7998, 2006.
VLCKOVÁ, R.; SOPKOVÁ, D.; POSIVÁK， J.; VALOCKY, I. Ovarian follicular atresia of ewes during spring puerperium. Veterinary Medicine International, London, v. 77, n. 1, p. 1-6, 2012.

WAGENMAKER, E. R.; BREEN, K. M.; OAKLEY, A. E.; TILBROOK, A. J.; KARSCH, F. J. Psychosocial stress inhibits amplitude of gonadotropin-releasing hormone pulses independent of cortisol action on the type II glucocorticoid receptor. Endocrinology, Washington, v. 150, n. 2, p. 762-769, 2009.

ZDUNCZYK, S.; MILEWSKI, S.; BARAŃSKI, W.; JANOWSKI, T.; SZCZEPAŃSKI, W.; JURCZAK, A.; RAŚ, A.; LEŚNIK, M. Postpartum uterine involution in primiparous and pluriparous polish longwool sheep monitored by ultrasonography. Bulletin of the Veterinary Institute Pulawy, Pulawy, v. 48, n. 1, p. 255 257, 2004. 
